Purdue University Purdue e-Pubs

Libraries Research Publications

9-1-1996

\title{
Post-Cold War National Security Policy: A Survey of U.S. Government Print and Internet Literature, 1990-1995
}

Bert Chapman

Purdue University, chapmanb@purdue.edu

Follow this and additional works at: http://docs.lib.purdue.edu/lib_research

Chapman, Bert, "Post-Cold War National Security Policy: A Survey of U.S. Government Print and Internet Literature, 1990-1995" (1996). Libraries Research Publications. Paper 62.

http://docs.lib.purdue.edu/lib_research/62

This document has been made available through Purdue e-Pubs, a service of the Purdue University Libraries. Please contact epubs@purdue.edu for additional information. 


\title{
Post-Cold War National Security Policy:
}

\section{A Survey of U.S. Government Print AND INTERNET LITERATURE, 1990-1995}

\author{
Bert Chapman
}

\section{INTRODUCTION}

The conclusion of the Cold War rivalry between the United States and former Soviet Union in the late 1980 s and early $1990 \mathrm{~s}^{1}$ created new areas of opportunity and concern for U.S. national security policy. No longer menaced by the threat of nuclear war from Soviet military might, the United States emerged from the Cold War as the world's preeminent military power. Successful developments such as this often produce elation in the pronouncements of U.S. officials as a recent Clinton administration declaration demonstrates:

Our military might is unparalleled. We now have a truly global economy linked by an instantaneous communications network, which offers opportunity for American jobs and American investment. The community of democratic nations is growing enhancing the prospects for political stability, peaceful conflict resolution, and greater dignity and hope for the people of the world. The international community is beginning to act together to address pressing global environmental needs.

Chapman is government publications coordinator/ reference librarian, assistant professor of library science, Purdue University Libraries, West Lafayette, Indiana, chapmanb@sage.cc.purdue.edu.

Never has American leadership been more essential to navigate the shoals of the world's new dangers and to capitalize on its opportunities. America's assets are unique: our military strength, our dynamic economy, our powerful ideals and, above all, our people. We 
can and must make the difference through our engagement; but our involvement must be carefully tailored to serve our interests and priorities. $^{2}$

However, the post-Cold War national security environment remains fraught with diverse perils to U.S. interests such as bitter internecine ethnic conflicts, nuclear proliferation, terrorism, militant Islamic fundamentalism, and conditions favoring conventional warfare in the absence of the restraining influence of the United States and Soviet Union on their respective client states. One military affairs thinker makes the following assessment:

Now that the Cold War no longer suppresses hot wars, the entire culture of disciplined restraint in the use of force is in dissolution. Except for Iraq's wars, the consequences have chiefly been manifest within the territories that had been Soviet, as well as Yugoslav. The protracted warfare, catastrophic destruction, and profuse atrocities of eastern Moldavia, the three Caucasian republics, parts of Central Asia, and lately Chechnya, Croatia, and Bosnia have certainly horrified and moved many Americans. But this diverse violence derives from the same postimperial devolution of epic, unprecedented scale or from purely localized sources.... The fighting between Ecuador and Peru, the mounting recklessness manifest between Greece and Turkey, and also perhaps Pakistan's increasing boldness over Kashmir suggest the more sinister possibility that a new much less restrained culture of war is emerging and spreading far and wide. Nothing is now countering a number of perverse precedents. Aggression and willful escalation alike remain unpunished; victors remain in possession of their gains; the defeated are abandoned to their own devices. It was not so during the Cold War, when most antagonists had a superpower patron with its own reasons to control them, victors had their gains whittled down by superpower compacts, and the defeated were often assisted by whichever superpower was not aligned with the victor. ${ }^{3}$

Despite being the world's leading power in this chaotic security environment, the U.S.' ability and willingness to respond to all national security threats remains problematic. The absence of a superpower rival, continuing federal budget deficits, and clamor for diverting defense expenditures toward perceived domestic public policy needs have resulted in reduced defense spending and smaller American armed forces during an era of enhanced and visible international upheaval. ${ }^{4}$

Cold War termination has also produced a resurgence in American isolationist sentiment toward global affairs exacerbated by displeasure over U.S. military operations in Somalia and projected military involvement in Bosnia. Documented indication of public reluctance to use U.S. military power comes from a 1993 opinion survey finding that protecting American oil supplies and preventing nuclear proliferation were the only foreign policy goals shared by the general public and opinion leaders in professional fields such as business, religion, and science. ${ }^{5}$

This ambivalence about the use of force and the proper role of U.S. military might is also reflected in U.S. government literature and policy pronouncements during the early 1990s. National security policy and strategy issues addressed in this voluminous literature include regional threats to U.S. security such as Iran, Iraq, North Korea, nuclear proliferation, converting U.S. defense industries to civilian production, the economic impact of military force reduction and base closings, examination of current and potential weapon systems, the propriety of openly allowing military service by homosexuals, women serving in combat, controversies over U.S. military forces performing peacekeeping operations and serving under foreign command, and conflict over the proper roles of the president and Congress in national security policymaking.

These and other issues will continue confronting U.S. national security policymakers and public opinion for the foreseeable future. This work documents and annotates current and recent historical U.S. government national security policy literature in print and electronic formats including Internet. Individuals studying this literature will find it intellectually stimulating and generally reflecting rigorous thought and analysis from members of Congress, congressional support agencies, the president, Department of Defense, and various branches of the armed services. These works present often diverse viewpoints on the significance of and possible answers to national security issues confronting the United States. Careful study, analysis, and synthesis of these publications can help produce better informed citizens and strengthen our ability to understand and respond effectively to the national security challenges and opportunities facing the United States at the close of the twentieth century. 


\section{BIBLIOGRAPHY}

\section{Armed Service Branches}

U.S. Congress. House Committee on Armed Services. Reserve and Guard Effectiveness. Washington, DC: GPO, 1993. SuDocs no.: Y 4.AR 5/2A:993-94/6. Item: 1012-A. ISBN 0-16-041443-1. 287p.

These hearings before the Military Forces and Personnel Subcommittee of the House Armed Services Committee during April 1993 addressed active and reserve military force structures and possible reforms (augmenting the early deployment capability and combat proficiency of the army guard and reserves contained in a Rand Corporation study.

Principal witnesses include Assistant Marine Corps Commandant General Walter Boomer; William D. Clark, acting assistant secretary of the army for manpower and reserve affairs; Richard Davis of the General Accounting Office's National Security and International Affairs Division; Rand Corporation study director Bernard K. Roster; and Lt. General John H. Tilelli, Jr., the army's deputy chief of staff for operations and plans.

Documentary materials incorporated in the transcript include the Rand Corporation study Assessing the Structure and Mix of Future Active and Reserve Forces and the final report of the U.S. Army Reserve Command Independent Commission.

U.S. Department of Defense. United States Special Operations Forces Posture Statement. Washington, DC: GPO, 1994. SuDocs no.: D 1.98:994. Item: 0306-F.

Special operations forces are elite forces who are highly trained to be used in environments such as hostage rescue that are unsuitable for conventional military forces.

This document provides an overview of U.S special operation forces activities, global and regional special forces strategies, and new challenges and technologies confronting special forces.

Appendixes profile programs such as air and maritime mobility, command, control, communications, computers, and intelligence, force structure information, detailed budgetary requests, and a glossary.

U.S. Department of the Navy. Fiscal Years 1992-1993 Report to the Congress. Washington, DC: GPO, 1991. SuDocs no.: D 201.1:992-93. Item: 0399-E. 56p.

This annual report presented to Congress by the U.S. navy reviews navy and marine corps operational postures and provides budget request justifications. Topics addressed in the navy's presentation include naval successes during Operation Desert Storm, naval forces in the post-Cold War era, sealift, surface warfare, submarine and anti-submarine warfare, and counternarcotics operations.

Subjects covered in the marine corps presentation include amphibious lift, maritime prepositioning, strategic airlift, ground combat, recruiting, retention, training, and education.

\section{Arms Control}

U.S. Congress. Senate Committee on Foreign Relations. Fiscal Year 1994 Arms Control Impact Statements. Washington, DC: GPO, 1993. SuDocs no.: Y 4.F 76/2-11:994. Item: 1039-A. ISBN 0-16-041559-4. $42 \mathrm{p}$.

This is an annual summary of U.S. weapons systems and their effect on arms control activities prepared by the Arms Control and Disarmament Agency (ACDA) for congressional foreign relations committees.

It outlines U.S. arms control policy as well as the impact of existing arms control agreements on U.S. strategic offensive systems, ballistic missile defense, and chemical weapons.

\section{Defense Economics}

U.S. Congress. House Committee on Armed Services. Reinvestment of Defense Resources for Economic Growth. Washington, DC: GPO, 1993. SuDocs no.: Y 4.AR 5/2A:991-92/78. Item: 1012-A. ISBN 0-16040903-9. 171p.

This hearing examines ways to reinvest funds previously devoted to defense spending to foster national economic growth. Witnesses testifying before this 20 May 1992 hearing consisted of government officials and corporate executives. Individuals appearing include then-New York Governor Mario Cuomo; former Texas Lt. Governor William Hobby; Roger Brinner, the executive director of DRI/McGraw-Hill; Katherine Gillman of Congress' Office of Technology Assessment; Lanxide Corporation President and CEO Marc S. Newkirk; Robert Raerner, the former director of the defense department's Office of Economic Adjustment; and Competitiveness Policy Council Executive Director Howard Rosen.

U.S. Congress. Office of Technology Assessment. After the Cold War: Living with Lower Defense Spending. Washington, DC: GPO, 1992. SuDocs no.: Y 3.T 22/2:2 C 67. Item: 1070-M. ISBN 0-16-036108-7. Stock number 052-003-01274-0. 237p. \$12.

This examination of the effects of the defense build-down on civilian economic activity emphasizes ways to handle worker and community dislocation stemming from defense spending reductions. 
Seven chapters analyze economic issues pertinent to post-Cold War defense expenditurecutbacks. Report summaries and findings are addressed in the introductory chapter. Subsequent contents chronicle germane public policy issues and options, confronting displaced defense workers, unique employment problems facing displaced defense engineers, veterans, state and community adjustment problems, and readjustment issues for defense companies. An appendix features defense spending and employment statistics.

U.S. Congress. Office of Technology Assessment. Arming Our Allies: Cooperation and Competition in Defense Technology. Washington, DC: GPO, 1990. SuDocs no.: Y 3.T 22/2:2 Al 5. Item: 1070-M. Stock number 052-003-01189-1. \$5. 113p.

Collaboration with U.S. allies proved an essential factor in the Cold War triumph of the west. This collaboration took many forms including the sharing of national technological expertise.

This report studies the status of the U.S. defense industry, its relationship with defense industries of allied nations, and the ability of the U.S. defense industry to meet future national security needs. Specific chapters address defense technology interdependence, congressional policy issues such as defense industry protection, integrating defense and civilmanufacturing, U.S. military dependence on foreign technology, comparable European military technology policies, U.S.-Japanese defense industry collaboration, and commercial implications of defense industry collaboration. Appendixes analyze organizational structures, techniques, and mechanisms for cooperation, Japanese defense policymaking and industry, and South Korean defense industry goals and strategies.

U.S. Congress. Office of Technology Assessment. U.S. Oil Import Vulnerability: The Technical Replacement Capacity. Washington, DC: GPO, 1991. SuDocs no.: Y 3.T 22/2:2 Oi 5/11. Item: 1070-M. ISBN 0-16035609-1. 136p.

This report updates a similiar Office of Technology Assessment (OTA) report from 1984 and examines U.S. technical capacity to replace oil imports lost due to supply disruption.

An introductory chapter examines the international and U.S. petroleum markets emphasizing U.S. petroleum production and consumption patterns. Additional report contents address the multiple uses of oil in U.S. economic activity, U.S. technical potential for oil import replacement, economic aspects of oil replacement strategies, and U.S. energy policy and technologies for oil import replacement.
An appendix features maps of U.S. Petroleum Allocation for Defense (PAD) Districts and North American Reliability Council (NERC) regions.

United States. Defense Base Closure and Realignment Commission. Defense Base Closure and Realignment Commission: 1993 Report to the President. Washington, DC: GPO, 1993. SuDocs no.: D 1.2:B 27/993. Item: 0306.

The conclusion of the Cold War resulted in the need for fewer military bases. The political controversy and economic dislocation of military bases led to the creation of a commission to recommend which military bases should be closed or given realigned missions. This document lists the findings of the Defense Base Closure and Realignment Commission.

The report opens with a cover letter to the president, map of major closures and realignments, and an executive summary. The principal chapter lists bases by armed service branch along with existing operational costs and projected closure savings. Subsequent chapters cover issues for future consideration in the base closure process such as depot capacity, historical base closure information, and military service assessments of the base closure process.

The appendix lists the text of Public Law 101-510 the Defense Base Closure and Realignment Act of 1990, base relocation closure criteria, and commission hearings.

U.S. General Accounting Office. DOD Force Mix Issues: Greater Reliance on Civilians in Support Roles Could Provide Significant Benefits. Washington, DC: GPO, 1994. SuDocs no.: GA 1.13:NSIAD-95-5. Item: 0546-D. 55p.

This examination of the Department of Defense's (DOD) use of civilian personnel in military support activities contends that the DOD could achieve significant personnel cost reductions by using civilian employees, consequently releasing military personnel for combat duties. Additional factors mentioned are the presence of impediments limiting the future replacement of military support personnel with civilians, the need for improved planning for future civilian deployments, and the presence of prior efforts to replace military positions with civilian personnel.

\section{Government Policy}

President of the United States. A National Security Strategy of Engagement and Enlargement. Washington, DC: GPO, 1995. SuDocs no.: PR 42.2:SE 2/995. Item: 0850. 33p.

This report notes the Clinton administration's national security objectives submitted in compliance 
with Section 603 of the Goldwater-Nichols Defense Department Reorganization Act of $1986 .{ }^{6}$

It opens with an introduction stressing the importance of the Defense Department's Bottom Up Review of national security policy. Further features emphasize administration efforts against terrorism, drug trafficking, and proliferation. Other sections stress the importance of enhancing U.S. access to foreign markets, energy security, and the promotion of sustainable development and democracy.

Coverage is given to geographic regions of U.S. strategic concern such as Europe and Eurasia, the Middle East, Southwest and South Asia, and Africa.

The conclusion maintains that the U.S. cannot isolate itself from global developments and that American engagement overseas requires the sustained support of the American people and Congress. ${ }^{7}$

President's Council of Advisors on Science and Technology. Science, Technology, and National Security. Washington, DC: GPO, 1992. SuDocs no.: PR 41.8:SCI 2. Item: 0851-J. 14p.

Examining the relationship between science, technology, and national security, the principal sections of this effort focus on scientific and technological contributions to intelligence collection, analysis, and assessment, proliferation as the primary future national security concern, the need for new governmental science and technology applications, attracting and retaining technically qualified individuals for sensitive national security positions, placing new emphasis on selected defensive weapon systems such as ballistic missile defenses, and enunciating a technological superiority strategy.

\section{U.S. Joint Chiefs of Staff. Joint Operation Planning} and Execution System Volume I (Planning Policies and Procedures)....Washington, DC: GPO, 1993. SuDocs no.: D 5.12:5-031. Item: 0315-C. 378p.

This document explains the doctrine, selected tactics, techniques, and procedures governing joint activities and performances by U.S. armed forces. Following the introduction, this compilation examines the joint planning process including the role of the National Security Council system. Other topics covered include the deliberate planning process, reviewing operation plans, crisis action planning, and the Joint Planning and Execution System (JOPES).

Report annexes feature a crisis action planning checklist, crisis reporting information, deployment preparation orders, evaluation response, concept development formats, and other materials.

U.S. Joint Chiefs of Staff. Joint Warfare of the Armed Forces of the United States. $2 \mathrm{~d}$ ed. Washington, DC:
GPO, 1995. SuDocs no.: D 5.12:1/995. Item: 0315-C. ISBN 0-16-0455-456. various pagings.

Contemporary warfare requires the successful integration of all military branches if national military objectives are to be achieved. This volume serves as a guide to joint action by U.S. armed forces and asserts that joint warfare is synonymous with the modern nature of war. Fundamentals of joint warfare according to this volume include unity of effort, concentrating military power, seizing and maintaining the initiative, agility, extending operations to the fullest breadth and depth, maintaining freedom of action, sustaining operations, clarity of expression, self-knowledge, and knowledge of the enemy.

Other contents examine the historical and contemporary roles of American military power, joint warfare values and fundamentals, and characteristics of joint military campaigns. An appendix features an afterword and joint chiefs of staff recommended readings on this subject.

U.S. Joint Chiefs of Staff. National Military Strategy of the United States. Washington, DC: GPO, 1992. SuDocs no.: D 5.2:M 59/2. Item: 0315. ISBN 0-16036125-7. 27p.

Published just after the collapse of the Soviet Union, this document is among the first to reflect the shift in American defense strategy from deterring Soviet aggression to focusing on regional threats to U.S. security.

Contents examine global and regional military trends and the importance of national security issues such as reducing illegal drug flow into the United States, ensuring access to foreign markets, mineral resources, oceans, and space, along with maintaining stable military balances to deter nations aspiring to regional military dominance.

Other sections examine foundations and principles of U.S. national security including strategic deterrence and defense, collective security, and maritime, aerospace, and technological superiority accompanied by power projection and decisive force. Emphasis is placed on force planning and employment along with the roles of U.S. forces domestically and internationally in implementing this strategy in a continuously evolving international security environment.

U.S. Joint Chiefs of Staff. National Military Strategy of the United States of America 1995: A Strategy of Flexible and Selective Engagement. Washington, DC: GPO, 1995. SuDocs no.: D 101.2:M 59/2/995. Item: 0325. ISBN 0-16-045531-6. 20p.

This is a declaration of response to the international security environment. It sees regional instability, the proliferation of mass destruction weapons, transnational 
dangers such as drug trafficking and terrorism, and threats to democratic reform in the former Soviet Union and eastern Europe representing the primary dangers confronting the U.S. military.

Responding to these threats requires successful integration of peacetime engagement; deterrence and conflict prevention; and war-fighting and winning in two simultaneous regional conflicts. National Military Strategy maintains that achieving these objectives requires high-quality personnel, readiness, force enhancement, modernization, and balance in a domestic environment that will see declines in active duty and reserve personnel through $1999 .^{8}$

\section{U.S. Joint Chiefs of Staff. Unified Action Armed Forces} (UNAAF). Washington, DC: GPO, 1995. SuDocs no.: D 5.12:0-2/995. Item: 0315-E.

This volume explains doctrines, policies, and principles governing the performance and activities of U.S. military forces. Specific sections cover Department of Defense functions, doctrine, and policy for joint command establishments, joint force components, and discipline and personnel administration.

U.S. Naval War College. Fundamentals of Force Planning: Vol. II: Defense Planning Cases. Newport, RI: Naval War College Press, 1991. SuDocs no.: D 208.202:F 82/991/V. 2. Item: 0408-A-01. Stock number 008-046-00143-0. 672p.

This second volume in a curriculum series for the Naval War College's National Security Decision Making Department focuses on broad force planning concepts and methodologies. Consisting of speeches and writings of scholars and national security policymakers, this treatise examines various national defense issues.

Contributions are oriented around chapters covering defense planning priorities, strategic nuclear force planning, regional perspectives on conventional force planning, strategic conventional force planning perspectives including land, aerospace, and maritime forces, and a concluding chapter emphasizing force planning synthesis.

\section{Intelligence and Information Warfare}

U.S. Central Intelligence Agency. Symposium on Teaching Intelligence October 1-2, 1993. Washington, DC: Center for the Study of Intelligence, 1994. 33p. (Non-depository; no SuDocs number)

Following a keynote address from Harvard University history professor Ernest May, the symposium addresses intelligence-related issues with perspectives from scholars, intelligence officers, and journalists. Topics addressed include intelligence support for policymaking, whether covert action can be a diplomatic tool, secrecy and accountability in a democracy, approaches to analysis in intelligence research, and emerging intelligence issues.

U.S. Congress. House Committee on Government Operations. Government Secrecy after the Cold War. Washington, DC: GPO, 1993. SuDocs no.: Y 4.G 74/7:G 74/15. Item: 1016-A. ISBN 0-16-041164-5. 424p.

This 18 March 1992 hearing by the Legislation and National Security Subcommittee examined government security procedures following the Cold War. Committee deliberations on this subject were also influenced by the Bush administration's desire to replace Executive Order (EO) 12356 issued by President Reagan in 1982 with a unified information security system applicable to government agencies and private industry.

Witnesses testifying before the committee include CIA Office of Public and Agency Information Director Gary Foster, then-House Foreign Relations Committee Chair Rep. Lee Hamilton (D-IN), Congressional Research Service American government specialist Fredrick Kaiser, Massachusetts Institute of Technology Professor of Science, Technology and National Security Theodore Postal, and Nina Stewart, the deputy secretary of defense for counterintelligence and security countermeasures.

An appendix features articles and other information on federal security classification including EO 12356.

U.S. Congress. House Committee on Science, Space, and Technology. Communications and Computer Surveillance, Privacy and Security. Washington, DC: GPO, 1994. SuDocs no.: Y 4.Sci 2:103-113. Item: 1025-A-01. ISBN 0-16-044530-2. 208p.

Conflict between national security and individual freedoms has been an important element in American political and constitutional history. A recent manifestation of this conflict was the Clinton administration's efforts to issue a federal encryption standard known as the Clipper Chip in order to facilitate electronic surveillance of telephone network modifications by intelligence and law enforcement agencies. The Clipper Chip received significant opposition from a variety of sources and is the subject of this 3 May 1994 hearing.

Witnesses appearing before the Science Committee's Subcommittee on Technology, Environment and Aviation include FBI Special Agent James Kallstrom; Clinton Brooks, special assistant to the director of the National Security Agency; Ray Krammer, deputy director of the National Institute of Standards and Technology (NIST); University of Pennsylvania telecommunications systems professor David Farber; 
Georgetown University Computer Sciences Chair Dorothy Denning; and Willis Ware, the chair of the Computer System Security and Privacy Advisory Board.

An appendix features pertinent press releases by Computer Professionals for Social Responsibility and the Electronic Privacy Forum Center, a report on the skipjack algorithm, FBI analysis of the proposed Digital Telephony and Communications Privacy Improvement Act of 1994, and recommendations from the Computer and Business Equipment Manufacturers Association on federal encryption policy.

U.S. Congress. House Select Committee on Intelligence. The Current and Future State of Intelligence. Washington, DC: GPO, 1994. SuDocs no.: Y 4.IN 8/18:IN 8/6. Item: 1009-B-06. ISBN 0-16-046367-X. $37 \mathrm{p}$.

Former CIA Director James Woolsey is the featured witness. Principal committee questioners are Rep. Dan Glickman (D-KS) and Rep. Larry Combest (R-TX). Areas of danger Woolsey sees for U.S. security interests include North Korea, the future of Russia, Ukraine, and other former Soviet republics, Iran, Iraq, Libya, nuclear proliferation, narcotics trafficking, and ethnic strife in the former Yugoslavia. Woolsey also emphasizes the intelligence community facing the twin challenges of modernizing in an era of personnel and resource constraints.

\section{National Security Politics}

Shuman, Howard E., and Walter R. Thomas, eds. The Constitution and National Security: A Bicentennial View. Washington, DC: National Defense University Press, 1990.

Conflict between the presidency and Congress over national security policy has been a historical and ongoing factor in American political life. This collection of essays examines various aspects of this conflict in three broad areas: dividing constitutional powers, the evolution of the presidency, and the constitution and foreign policy.

Specific topics covered include foreign policy and congressional/presidential relations, the power of the purse, presidential powers and national security, presidential transitions and national security issues, and the rise of a "presidential branch" of government. Additional essays confront the War Powers Act, the legitimacy of a congressional national security role, economics and foreign policy, the constitutional foundations of nuclear defense policy, legal and judicial facets of national security, and the constitutionality of strategic planning.
U.S. Congress. House Committee on Armed Services. An Assessment of the Bottom-Up Review. Washington, DC: GPO, 1994. SuDocs no.: Y 4.AR 5/2A:99394/45. Item: 1012-A. ISBN 0-16-046528-1. 152p.

Presented is a detailed congressional assessment of the military's Bottom-Up Review (BUR) from hearings on 1 and 22 March 1994. The 1 March hearing examined Joint Chiefs of Staff planning for the BUR while the 22 March hearing dealt with the impact of this report.

Witnesses appearing before the committee include retired Admiral Lee Baggett, the former commander-inchief (CINC) of the U.S. Atlantic Command; Eliot Cohen of Johns Hopkins University's School for Advanced International Studies; Rear Admiral Francis W. Lacroix of the secretary of defense's joint staff; Vice Admiral T. Joseph Lopez, the deputy chief of naval operations for resources warfare requirements and assessments; Arlington Institute President John L. Peterson; Russell E. Travers from the Defense Intelligence Agency; and retired Admiral Carlisle Trost, the former chief of naval operations.

U.S. Congress. House Committee on Foreign Affairs. Consideration of Draft Legislation on the Situation in the Persian Gulf. Washington, DC: GPO, 1991. SuDocs no.: Y 4.F 76/1:P 43/14. Item: 1017-A. 37p.

The purpose of this 9 January 1991 hearing was to consider House Concurrent Resolution 1, whose purpose was to achieve congressional authorization of any U.S. military action against Iraq. Principal witnesses were Representatives Charles Bennett (D-FL) and Richard Durbin (D-IL).

U.S. Congress. House Committee on Foreign Affairs. U.S. Post Cold War Foreign Policy. Washington, DC: GPO, 1993. SuDocs no.: Y 4.F 76/1:P 84/6. Item: 1017-A. ISBN 0-16-040010-4. 252p.

This series of hearings in May 1992 examines issues likely to influence U.S. foreign policy in the post-Cold War era.

Witnesses appearing before the committee include some of the primary foreign policymakers of this period. Those presenting testimony include former Secretaries of Defense Harold Brown, Clark Clifford, and James Schlesinger, former Secretary of State Alexander Haig, former presidential National Security advisors Richard Allen, Zbigniew Brzezinski, and McGeorge Bundy, and former CIA Directors William Colby and Stansfield Turner.

Topics discussed by committee members and witnesses include defining threats to U.S. security, possible contemporary foreign policy analogies to the post-World War I era, U.S. policy toward China, restructuring the U.S. foreign aid budget, U.S. leader- 
ship in shaping international security, restructuring the ABM Treaty, U.S. policy toward ethnic disputes in new nations, and multiple other subjects.

U.S. Congress. Senate Committee on Foreign Relations. The Peace Powers Act (S.5) and the National Security Revitalization Act (H.R. 7). Washington, DC: GPO, 1995. SuDocs no.: Y 4.F 76/2:S.HRG. 104-144. Item: 1039-A. ISBN 0-16-047600-3. 106p.

This 21 March 1995 hearing examines possible effects of the proposed Peace Powers and National Security Revitalization acts on U.S. policy toward United Nations peacekeeping operations.

Individuals testifying include Permanent U.S. Representative to the United Nations Madeleine Albright, former Tennessee Senator and White House Chief of Staff Howard Baker, Senator Robert Dole (RKS), Marine Corps Lt. Colonel Robin Higgins, Jeanne Kirkpatrick of the American Enterprise Institute, and Foreign Policy editor Charles Maynes.

U.S. General Accounting Office. Bottom-Up Review: Analysis of Key DOD Assumptions. Washington, DC: GPO, 1995. SuDocs no.: GA 1.13:NSIAD-95-56. Item: 0546-D. 69p.

This is an analysis of the Defense Department's "Bottom-Up Review" of anticipated national military requirements. The report findings conclude that the defense department failed to completely analyze its assumptions about force availability and enhancement, supporting capabilities, and the funding required for the two-conflict strategy espoused in the "Bottom-Up Review."

\section{Peacekeeping}

National Defense University. Institute for National Strategic Studies. Peace Support Operations and the U.S. Military. Dennis J. Quinn, ed. Washington, DC: National Defense University Press, 1994. SuDocs no.: D 5.402:P 31/3. Item: 0378-H-01. 235p.

The use of U.S. military forces in peacekeeping operations in areas such as Somalia, Haiti, and the former Yugoslavia remains a source of significant debate and controversy. Such controversy has been augmented by disagreement over whether U.S. forces should participate in United Nations peacekeeping operations under the command of non-American officers.

This collection of essays by U.S. and foreign military officers, a member of Congress, and U.S. policymakers examines various military and public policy aspects of peacekeeping. Essay topics address peacekeeping implications for the U.S. military, the U.S. military role in a multilateral peacekeeping framework, internationalmilitaryofficers'perspectives on peace support operations, peacekeeping in Europe's Partnership for Peace, assessment of a proper U.S. role in peacekeeping by Senator John McCain (R-AZ), crisis management in the former Yugoslavia, and peacekeeping in the western hemisphere, Europe, Africa, and the Middle East.

National Defense University. Peacemaking, Peacekeeping and Coalition Warfare: The Future of the United Nations: Proceedings of a Conference Cosponsored by National Defense University and Norwich University. Fariborz L. Mokhtari, ed. Washington, DC: National Defense University Press, 1994. SuDocs no.: D5.402:P 31/6. Item: 0378-H-01. 293p.

The end of the Cold War has seen the re-emergence of instability, ethnic conflict, and national disintegration on a global scale. These new realities and the inability of the United States and other major powers to impose unilateral peace make coalition and United Nations peacekeeping efforts increasingly important. This document represents the proceedings of a conference on peacemaking and peacekeeping consisting of policymakers, scholars, and defense experts. Presentation topics include the influence of the information revolution on military decisionmaking, increasing demands on reduced fiscal resources and military forces, empowering the United Nations with combat instead of peacekeeping forces, French peacekeeping efforts, command and control in multinational peacekeeping operations, advocacy of imposing international law and order standards, and gaps between peacekeepers and war and the implications of these gaps for U.S. military forces. Other issues addressed include the legal dilemma of humanitarian intervention, naval aspects of an expanded military role, geography's importance in peacekeeping operations, conditions in Operation Desert Storm, nuclear proliferation, and a historical analysis of the Axis alliance during World War II.

U.S. Congress. House Committee on Armed Services. The Impact of Peacekeeping on Army Personnel Requirements. Washington, DC: GPO, 1994. SuDocs no.: Y 4.AR 5/2A:993-94/28. Item: 1012-A. ISBN 016-043975-2. 151p.

This 27 October 1993 hearing examines the effect of peacekeeping on army personnel requirements in light of the Clintonadministration'sBottom-UpReview calling for U.S. military forces to have the personnel to win two simultaneous major regional conflicts.

Witnesses appearing before the committee include former Army Staff Senior Fellow Raoul Henri; Brigadier General William Bolt, the director of army force programs integration; retired General Maxwell Thur- 
man, the former commander of the U.S. southern command; former Army Chief of Staff General Carl Quono; and Edward L. Warner III, the assistant becretary of defense for strategy requirements and tesources.

U.S. Congress. House Committee on Armed Services. Peacekeeping Budget, Plans and Actions. Washington, DC: GPO, 1995. SuDocs no.: Y 4.AR 5/2A:99394/46. Item: 1012-A. ISBN 0-16-046527-3. 49p.

This 12 April 1994 hearing by the Oversight and Investigations Subcommittee of the House Armed Jervices Committee examined the Clinton administraon's proposal to have the Defense Department budget pay for $\$ 300$ million worth of United Nations peacekeeping responsibilities. Witnesses appearing before this panel include Rear Admiral F.L. Bowman, the joint chiefs of staff deputy director of politico-military affairs; and Assistant Secretary of Defense for Strategy, Requirements and Resources Edward L. Warner.

The transcript includes the text of H.R. 3334, a bill imposing limits on placing U.S. military forces under foreign operational control on behalf of the United Nations.

U.S. Congress. Senate Committee on Armed Services. International Peacekeeping and Peace Enforcement. Washington, DC: GPO, 1994. SuDocs no.: Y 4.AR 5/3:S.HRG. 103-353. Item: 1034-A. ISBN 0-16043426-2. 74p.

This 14 July 1993 hearing by the Armed Services Committee's Subcommittee on Coalition Defense and Reinforcing Forces examines U.S. opportunities for participation in United Nations peacekeeping and peace enforcement missions.

Individuals testifying include former Senate Foreign Relations Committee professional staff member Bruce Rickerson; Undersecretary of Defense for Policy Frank Wisner; Karl Inderfurth, the U.S. alternate representative to the United Nations for special political affairs; Jonathan Dean from the Union of Concerned Scientists; Leon Edney, the former commander-in-chief of the U.S. navy's Atlantic Command; and Richard Armitage of Armitage Associates.

U.S. General Accounting Office. Peace Operations: Effect of Training, Equipment, and Other Factors on Unit Capability. Washington, DC: GPO, 1995. SuDocs no.: GA 1.13:NSIAD-96-14. Item: 0546-D. 50p.

This October 1995 report examines various factors affecting the ability of the U.S. military to perform international peacekeeping operations.

Issues covered include how armed services integrate peace operations into existing training programs, the impact of peace operations on combat readiness, and whether U.S. forces have the requisite weapon systems and equipment for such operations.

Findings demonstrate a divergence of opinion by ground unit commanders on the propriety of peace operations, that some commanders include peace operation training while others prefer combat training exclusively, and that peace operation participation enhances and restrains war-fighting capabilities.

\section{Reference}

U.S. Joint Chiefs of Staff. Joint Electronic Library on $C D-R O M$. Norfolk, VA: Joint Warfighting Center, 1993-. SuDocs no.: D 5.21. Item: 0315-C-03. System requirements: IBM PC or compatible, 286 or higher; 520K; DOS 2.0 or later, MS-DOS CD-ROM extensions (version 2.0 or later); CD-ROM drive, hard disk, and EGA, VGA, or Hercules graphics card for image viewing.

This annual CD-ROM features doctrinal and technical publications from various armed forces branches. Topics presented include an army manual on battlefield deception, marine corps manuals on combat stress and counterinsurgency operations, air force manuals on sea surveillance operations and airspace control in combat zones, joint chiefs policy memorandums, a defense department military terms dictionary, and other military-related publications.

\section{Security Issues}

Alves, Dora, ed. New Perspectives for U.S-Asia Pacific Security Strategy: The 1991 Pacific Symposium. Washington, DC: National Defense University Press, 1992. SuDocs no.: D 5.402:NP. Item: 0378-H-01. $197 \mathrm{p}$.

The Pacific Ocean has been an important factor in U.S. security both historically and contemporaneously. This volume examines Pacific security trends in the aftermath of Operation Desert Storm and changes in eastern Europe.

Topics addressed include moves toward Asian democratization and stability, Asian technology and military organization, and the impact of the 1970s world oil crisis and U.S. recession of the early 1990s on Asia. Additional topics receiving coverage include future Chinese and Japanese security policies, U.S.Japanese security cooperation, prospects for Korean Peninsula peace and reunification, Australian political and strategic interests in the 1990s, and the changing Pacific strategic environment from emphasis on U.S.Soviet rivalry to a series of multipolar relationships and security issues including international and bilateral trade. 
Blank, Stephen, et al. Responding to Low-Intensity Challenges. Maxwell Air Force Base, AL: Air University Press, 1990. SuDocs no.: D 301.26/6:C 76/5. Item: 9422-K. ISBN 0-16-029332-4. 318p.

The Cold War and post-Cold War international strategic environments feature numerous localized conflicts. Given proper political and strategic influence such conflicts can become of acute importance in international political discourse, and U.S. national interests.

Responding to Low-Intensity Conflict Challenges contains case studies of five such conflicts by military scholars. Conflicts covered include Middle Eastern lowintensity conflicts such as Algeria, the experience of Soviet forces in Afghanistan, internecine conflict in Guatemala and El Salvador, African conflicts (including the former South African government's regional intervention policies), and Philippine and Indonesian responses to revolutionary political violence.

Cronin, Patrick M., ed. From Globalism to Regionalism: New Perspectives on U.S. Foreign and Defense Policies. Washington, DC: National Defense University Press, 1993. SuDocs no.: D 5.402:G 51/2. Item: 0378H-01. 259p.

This series of essays examines the transformation of U.S. security interests from global competition with the Soviet Union to an emphasis on regional security concerns, with an opening address by General Colin Powell. Essay themes cover regional, international, and transnational aspects of U.S. foreign policy and national security. Specific subjects include post-Gulf War U.S. national security strategy in the Middle East, Northeast Asia's shifting balance of power, conflict potential in Southeast Asia and the South China Sea, and prospects for South Asian stability.

Presentations on other topics examine the strategic implications of population change, United Nations forces and regional conflicts, and environmental dimensions of national security.

Magyar, Karl P., et al., eds. Challenge and Response: Anticipating U.S. Military Security Concerns. Maxwell Air Force Base, AL: Air University Press, 1994. SuDocs no.: D 301.26/6:C 35. Item: 0422-K. 431p.

Consisting of two sections, the contents of this volume feature the contributions of U.S. Air Force officers and analysts.

Following an introductory overview of the emerging post-Cold War international order and conflict environment, the first section of this treatise examines challenges to U.S. security interests. Such challenges include Middle East conflict and confrontation, unresolved security issues in the former Warsaw Pact region, arms control, proliferation, and changing military sociological concerns such as the controversy over homosexuals in the military.

Possible responses to these issues are discussed and analyzed in the second section. Topics examined include regional conflict management, forecasting military technological needs, military responses in nonpolitical conflicts, twenty-first-century air theory, economic warfare, developing military assets in space, and conflict termination.

National Defense University. Institute for National Strategic Studies. Strategic Assessment 1995: U.S. Security Challenges in Transition. Hans Binnendijk and Patrick Clawson, eds. Washington, DC: National Defense University and GPO, 1995. SuDocs no.: D 5.402:IN 7/4. Item: 0378-H-01. ISBN 0-16-045367-4. 205 p.

This report examines various challenges to U.S. national security interests by a variety of scholars. Contents include an overview of the current international strategic setting and examination of security issues in geographic regions such as the Middle East, Europe, and elsewhere. Other topics discussed include the role of oceans in international security, the increasing number of countries possessing mass destruction weapons, U.S. force structure, arms transfer and export controls, information technologies, peace operations, transnational threats, and economics.

U.S. Congress. Commission on Security and Cooperation in Europe. Implementation of the Helsinki Accords: Bosnia's Second Winter under Siege. Washington, DC: GPO, 1994. SuDocs no.: Y 4.SE 1:103-2-12. Item: 1089-C. ISBN 0-160044082-3. 55p.

This 8 February 1994 hearing examines the civil war in Bosnia and possible U.S. responses to this conflict. Witnesses appearing before the commission include Refugees International President Lionel A. Rosenblatt, Kemal Kurspahic, the editor of Sarajevo newspaper Oslobodjenjie, and former Assistant Secretary of Defense Leonard Sullivan, Jr.

The appendix features opening statements by commission members and selected witnesses along with the report of commission member Representative Frank Wolf (R-VA) on his January 1994 trip to Bosnia.

U.S. Congress. House Committee on Armed Services. Administration's Plan for Continued U.S. Military Participation in UN Operations in Somalia. Washington, DC: GPO, 1994. SuDocs no.: Y 4.AR 5/2A:99394/29. Item: 1012-A. ISBN 0-16-044031-9. 90p.

U.S. participation in United Nations operations in Somalia became particularly controversial as U.S. peacekeeping forces suffered casualties there in 1993. This 21 October 1993 hearing examines the Clinton 
administration's 13 October 1993 report to Congress on the administration's Somalia policy.

Witnesses testifying before the committee include former Assistant Secretary of Defense for International Security Affairs R.L. Armitage; American University law professor Tom Farer; Lt. General Robert B. Johnston the marine corps deputy chief of staff for manpower and reserve affairs; F. Andy Messing, the executive director of the National Defense Council Foundation; and Ambassador Mohamed Sahnoun of the International Development Center.

U.S. Congress. House Committee on Armed Services. Building a Defense That Works for the Post-Cold War World. Washington, DC: GPO, 1991. SuDocs no.: Y 4.AR 5/2A:989-90/83. Item: 1012-A. 416p.

These series of hearings from February-April 1990 before the committee's Defense Policy Panel examine national security issues in light of recent eastern European political transformations.

Issues covered by these hearings include the B-2 bomber, future contingency force requirements, technical stockpiling and the proper defense industrial base, strategic modernization and arms control, U.S. power projection, declining overseas bases and defense resources, and the status of the Soviet military.

Multiple witnesses testifying during these hearings include Martin Marietta Chair Norman Augustine, General Accounting Office National Security and International Affairs Division Assistant Comptroller General Frank C. Conahan, Defense Department Assistant Secretary for International Security Policy Stephen J. Hadley, former Navy Secretary John Lehman, Stephen Meyer of the Center for International Studies at the Massachusetts Institute of Technology (MIT), and Joint Chiefs of Staff Chair General Colin Powell.

U.S. Congress. House Committee on Armed Services. Crisis in the Persian Gulf: Sanctions, Diplomacy and War. Washington, DC: GPO, 1991. SuDocs no.: Y 4.AR 5/2A:989-90/57. Item: 1012-A. 920p.

This series of December 1990 hearings examines the U.S. Persian Gulf policy in light of events since Iraq's 2 August 1990 invasion of Kuwait.

Witnesses testifying during these hearings include Secretary of Defense Dick Cheney, former British Prime Minister Edward Heath, former U.S. Representative to the United Nations Jeane Kirkpatrick, William Quandt of the Brookings Institution, former Undersecretary of State for Political Affairs Joseph Sisco, former Secretary of State Cyrus Vance, and Central Intelligence Agency (CIA) Director William Webster.

The transcript also includes essays by committee chair Les Aspin (D-WI) on the role of sanctions in securing the U.S.' Persian Gulf interests, diplomatic achievement of interests of the United States in this area, and the consequences of military action in the Persian Gulf.

U.S. Congress. House Committee on Armed Services. The Impact of the Persian Gulf War and the Decline of the Soviet Union on How the United States Does Its Defense Business. Washington, DC: GPO, 1991. SuDocs no.: Y 4.AR 5/2A:991-92/17. Item: 1012-A. ISBN 0-16-037105-8. 974p.

Transcripts of the House Armed Services Committee hearings between February and June 1991 examine various national security issues. Topics addressed include the fairness of the all-volunteer military, Patriot missile performance in Operation Desert Storm and its visible implications for the Strategic Defense Initiative, high technology equipment performance in Desert Storm, the military reform agenda after Desert Storm, and the sustainability and recruiting of the all-volunteer force.

Principal witnesses include Doug Bandow of the CATO Institute, Harvard University Public Policy Professor Albert Carnesale, Defense Department Comptroller Sean O'Keefe, General H. Norman Schwarzkopf, and additional military personnel, policymakers, and scholars.

U.S. Congress. House Committee on Armed Services. The Link Between Force Structure and Manpower Requirements. Washington, DC: GPO, 1993. SuDocs no.: Y 4.AR 5/2A:993-94/5. Item: 1012-A. ISBN 0-16041390-7. 238p.

Primary subcommittee members testifying include committee chair Representative Ike Skelton (D-MO) and ranking member Representative Jon Kyl (R-AZ). Witnesses appearing before the committee were Rear Admiral Dennis C. Blair, the deputy director for force structure and resources force structure from the Joint Chiefs of Staff Resources and Assessment Directorate, Chief of Naval Operations Admiral Frank Kelso, Air Force Chief of Staff General Merrill McPeak, Marine Corps Commandant Carl E. Mundy, Jr., and Army Chief of Staff General Gordon R. Sullivan.

U.S. Congress. House Committee on Armed Services. The Policy Implications of U.S. Involvement in Bosnia. Washington, DC: GPO, 1994. SuDocs no.: Y 4.AR 5/2A:993-94/24. Item: 1012-A. ISBN 0-16-043646-X. $72 \mathrm{p}$.

These 25-26 May 1993 hearings examined foreign policy and military implications of increased U.S. military involvement in Bosnia.

Individuals testifying before the committee included retired Army General John Galvin; retired 
Canadian Major General Lewis Mackenzie, the former commander of United Nations forces in Sarajevo; Daniel T. Pleseher, the director of the British American Security Information Council; and Susan Woodward of the Brookings Institution.

U.S. Congress. House Committee on Foreign Affairs. Challenges to U.S. Security in the 1990's. Washington, DC: GPO, 1994. SuDocs no.: Y 4.F 76/1:SE 2/24. Item: 1017-A. ISBN 0-16-046456-0. 187p.

The series of hearings conducted during 1994 by the House Foreign Affairs Committee's Subcommittee on International Security, International Organizations, and Human Rights covered institution-building in postCold War Europe, building domestic support for foreign policy, international organized crime and nuclear security, and the strengths and weaknesses involved in building open democratic societies.

Witnesses appearing before the committee included Zbigniew Brzezinski of the Center for Strategic and International Studies, former Secretary of State Lawrence Eagleburger, former House Foreign Affairs Committee Chair Dante Fascell (D-FL), then-CIA Director James Woolsey, Leonard Spector of the Carnegie Endowment for International Peace, and Thomas Cochran from the Natural Resources Defense Fund.

U.S. Congress. Office of Technology Assessment. American Military Power: Future Needs, Future Choices. Washington, DC: GPO, 1991. SuDocs no.: Y 3.T 22/2:2 Am 3/4. Item: 1070-M. ISBN 0-16035962-7. Stock number 052-003-01263-4. 28p.

This background paper assesses future U.S. military needs. Topics covered include the post-World War II security environment and the evolution of American military doctrine. Additional topics covered include U.S. national security objectives and policies, the future global security environment, and choices for reaching national security objectives including determining the size of threat, U.S. force readiness, allied interdependence, and weapons performance.

Incorporated in this report are statistics on major national military budgets, active armed forces personnel, and an inventory of countries producing military weapons.

U.S. Congress. Senate Committee on Foreign Relations. The Future of NATO. Washington, DC: GPO, 1994. SuDocs no.: Y 4.F 76/2:S.HRG. 103-564. Item: 1039-A. ISBN 0-16-044425-X. 123p.

The 1-23 February 1994 joint hearings of the Senate Foreign Relations and Armed Services Committees examine the future of the North Atlantic Treaty
Organization (NATO) in light of events in Bosnia and prospects for NATO expansion into eastern Europe.

Individuals testifying include Lt. General Daniel Christman, the U.S. representative to the NATO Military Committee; U.S. Ambassador to NATO Robert Hunter; Assistant Secretary of State for European and Canadian Affairs Stephen Oxman; Defense Department Undersecretary for Policy Frank Wisner; retired Army General John Galvin; former U.S. Ambassador to the Conference on Security and Cooperation Max Kampelman; and former Secretary of Defense James Schlesinger.

An appendix lists questions submitted to selected witnesses by committee members and answers to those questions.

U.S. Congress. Senate Committee on Foreign Relations. U.S. Participation in Somalia Peacekeeping. Washington, DC: GPO, 1993. SuDocs no.: Y 4.F 76/2:S.HRG. 103-318. Item: 1039-A. ISBN 0-16043333-9. 119p.

U.S. participation in Somalian peacekeeping operations produced a number of contentious issues including whether U.S. forces should serve under the United Nations command.

These 19-20 October 1993 hearings saw members of the Senate Foreign Relations Committee grapple with this and other issues surrounding U.S. military activity in this strife-torn African nation. Witnesses appearing before the committee include Under Secretary of State for Political Affairs Peter Tarnoff, Under Secretary of Defense Walter Slocombe, and U.S. Ambassador to the United Nations Madeleine Albright.

An appendix features written responses to questions from committee members by Tarnoff and $\mathrm{Al}$ bright.

U.S. General Accounting Office. National Security: Impact of China's Military Modernization in the Pacific Region. Washington, DC: GPO, 1995. SuDocs no.: GA 1.13:NSIAD-95-84. Item: 0546-D. 50p.

This report examines Chinese military modernization efforts and how they compare with other Asian nations. Principal findings reveal that China is slowly changing its military force structure; that the Persian Gulf War demonstrated the obsolescence of Chinese military equipment and doctrine; that other Asian nations are modernizing their militaries; and that China will become increasingly important in international military matters.

U.S. General Accounting Office. National Security Issues. (Transition Series). Washington, DC: GPO, 1992. GA 1.33:93-9TR. Item: 0575. 42p. 
This compilation includes a volume from a series of reports on public policy issues prepared by the General Accounting Office (GAO) for incoming Clinton administration officials and 103d Congress leaders.

Covering national security issues, this work emphasizes subjects such as managing defense spending reductions without compromising U.S. military force quality. Other issues analyzed include reassessing U.S. military roles, missions, force commitments, and security assistance programs.

Subsequent sections emphasize controlling the spread of mass destruction weapons, weapons system acquisition reform, environmental challenges such as destroying chemical weapons stockpiles, executing existing inventory and management improvement initiatives, and improving armed services financial management.

Wilborn, Thomas L. How Northeast Asians View Their Security. Carlisle Barracks, PA: Strategic Studies Institute U.S. Army War College, 1991. SuDocs no.: D 101.2:As 4. Item 0325. 85p.

Northeast Asian nations such as China, Japan, Russia, North Korea, and South Korea play important roles in U.S. national security interests. This work examines the views of northeast Asian defense intellectuals toward the national security environment of their respective nations and the significance of their assessments for the United States with particular emphasis on the U.S. army.

Following the introduction, this volume presents national security perspectives from China, Japan, and South Korea with a concluding chapter focusing on the implications of these opinions for the United States.

Work findings demonstrate that northeast Asian defense intellectuals believe the international political system is becoming more decentralized, U.S.-Russian and Sino-Russian detentes will last a decade or two at most, regional powers are less likely to be restricted by Cold War alliances in pursuing national interests, Chinese and Korean worries about Japan's future role following the expected regional disengagement of the United States, the strength of anti-Japanese stereotypes in Korea and China, and broad regional agreement that the U.S. military presence contributes to regional stability.

\section{Social Issues}

U.S. Congress. House Committee Armed Services. Assessment of the Plan to Lift the Ban on Homosexuals in the Military. Washington, DC: GPO, 1994. SuDocs no.: Y 4.AR 5/2A:993-94/19. Item: 1012-A. ISBN 016-043494-7. 379p.
No Clinton administration national security policy initiative has been as controversial as its effort to lift the longstanding prohibition on homosexuals serving openly in the military. These 21-23 July 1993 hearings by the House Armed Services Committee's Military Forces and Personnel Subcommittee examine the implications of the Clinton administration's “Don't Ask Don't Tell" policy regarding homosexuals in the armed forces. Witnesses testifying include former Defense Secretary Les Aspin, military officers such as former Joint Chiefs of Staff Chairman General Colin Powell, Defense Department General Counsel Jamie Gorelick, and constitutional law scholars Cass Sunstein and David Schlueter of the University of Chicago and St. Mary's University law schools.

U.S. Presidential Commission on the Assignment of Women in the Armed Forces. Report to the President. Washington, DC: The Commission, 1992. SuDocs no.: PR 41.8:W 84. Item: 0851-J. ISBN 0-16-038236-X.

This presidential commission report covers the roles of women in the armed forces including serving in combat. Opening with a transmittal letter to former President Bush, the initial section lists issues such as fitness/wellness standards, basic training standards, parental and family policies, combat roles for women, and conscription along with commission recommendations over appropriate female participation in these areas.

Subsequent sections feature alternative commissioner views on some of the aforementioned subjects and appendixes such as the statute establishing this commission, current laws and policies regarding female armed forces assignment, panel fact-finding research results, opinion polls, fact-finding trips, meeting agendas, witness list, and commissioner biographies.

\section{Weapons Systems}

U.S. Congress. House Committee Armed Services. Future Nuclear Weapons Requirements. Washington, DC: GPO, 1992. SuDocs no.: Y 4.AR 5/2A:99192/76. Item: 1012-A. ISBN 0-16-040798-2. 100p.

This 8 April 1992 hearing by the Defense Policy and the Department of Energy Nuclear Facilities Panels of the House Armed Services Committee examines perspective changes in U.S. nuclear weapons requirements in light of global political changes.

Witnesses testifying include former U.S. Air Force Secretary Thomas Reed and Michael May, the former director of the Lawrence Livermore National Laboratory. Topics addressed include nuclear proliferation, ballistic missile defenses, and nuclear weapons handling by post-Soviet republics. 
U.S. Congress. House Committee on Foreign Affairs. U.S. Nuclear Policy. Washington, DC: GPO, 1995. SuDocs no.: Y 4.F 76/1:N 88/25. Item: 1017-A. ISBN 0-16-046851-5. 97p.

This 5 October 1994 hearing examined U.S. nuclear weapons policies. Principal witnesses include Deputy Secretary of Defense John Deutsch; Ashton Carter, the Defense Department's assistant secretary for international security policy; and Defense Department Undersecretary for Policy Walter Slocombe.

Subjects covered during this hearing include U.S. moves to a smaller and safer nuclear force structure, nuclear strategy and targeting, the status of arms control agreements, U.S. nuclear weapons use policy, the pace of Russian nuclear drawdown, AntiBallistic Missile (ABM) treaty value, and prospects for a comprehensive nuclear weapons test ban.

Appendixes include a letter from then-committee chair Representative Lee Hamilton (D-IN) to former Secretary of Defense Les Aspin and witness' responses to committee members' questions.

U.S. Congress. Senate Committee on Armed Services. Briefing on Results of the Nuclear Posture Review. Washington, DC: GPO, 1994. SuDocs no.: Y 4.AR 5/3:S.HRG. 103-870. Item: 1034-A. ISBN 0-16046373-4. 60p.

This 22 September 1994 hearing reviews the results of the Clinton administration's Nuclear Posture Review (NPR) following up on its 1993 Bottom-Up Review of U.S. military forces. Elements of the NPR that are covered include strategic and non-strategic forces, command, control, communications and intelligence, infrastructure requirements, and safety, security, and use control.

Witnesses appearing before the committee were then-Deputy Secretary of Defense John Deutsch and Admiral William Owen, the vice chair of the joint chiefs of staff.

Some sections of testimony are deleted for national security reasons.

U.S. Congress. Senate Committee on Government Affairs. Evaluation of the U.S. Strategic Nuclear Triad. Washington, DC: GPO, 1994. SuDocs no.: Y 4.G 74/9:S.HRG. 103-457. Item: 1037-B. ISBN 0-16043971-X. 128p.

During the Cold War the United States relied on its land-based, sea-based, and air-based nuclear weapons delivery systems as a principal component of national defense. This 10 June 1994 hearing examines findings of a General Accounting Office (GAO) study on the status of the U.S. nuclear triad.

Principal witnesses appearing before the committee include Secretary of Defense William Perry and Eleanor
Chelinsky, the assistant comptroller general for program evaluation at GAO.

The appendix features written questions submitted to Chelinsky and Perry by committee members on subjects such as the resumption of underground nuclear testing, the defense department's position on GAO's triad evaluation, and Minuteman III missile modernization.

U.S. General Accounting Office. Enhanced Fiber Optic Guided Missile: Need to Define Requirements and Establish Criteriato Assess Performance. Washington, DC: GPO, 1995. SuDocs no.: GA 1.13:NSIAD-96-7. Item: 0546-D. 28p.

This is a review of portions of the army's plan to acquire the Enhanced Fiber Optic Guided Missile (EFOG-M) as part of the Rapid Force Projection Initiative. Purposes of this system include engaging armored combat vehicles, important ground targets such as command, control, and communication centers, and helicopters at ranges up to 15 kilometers.

Report recommendations include the secretary of defense requiring the army to prepare a formal EFOG$M$ requirements document, comparative analyses with similar weapons systems including those from other armed services, and proof that deploying EFOG-M would be cost effective.

U.S. General Accounting Office. Export Controls: Some Controls over Missile-Related Technology Are Weak. Washington, DC: GPO, 1995. SuDocs no.: GA 1.13:NSIAD-95-82. Item: 0546-D. 29p.

This April 1995 report provides information on the Missile Technology Control Regime (MTCR) and U.S. missile technology-related exports to China. Report contents focus on the extent to which dual-use and missile technologies are exported to sensitive endusers such as the Chinese military, the ability of the United States to monitor Chinese compliance with the 1994 U.S.-China bilateral MTCR agreement, and the effectiveness of U.S. proliferation sanctions on China contained in Public Law 101-246.

Findings reveal that approximately $\$ 530$ million of missile-related technology items were approved by the U.S. government for export to China between 1990 and 1993, concern by the defense department that the commerce department is not identifying or seeking interagency approval of missile technology export license applications, and that existing licensing procedures and monitoring controls fail to ensure that missile technology exports are kept from sensitive end-users. 


\section{INTERNET SOURCES}

Increasing quantities of U.S. government information are being disseminated by the Internet with this international series of networks representing, in some cases, the only means by which growing amounts of government information are disseminated. This enhanced dissemination of information via Internet is also applicable to national security policy and strategy publications compiled by various branches of the armed services. One useful source for current legislative and regulatory information on military affairs is the Government Printing Office's GPO Access database. Consisting of the Federal Register, Congressional Record, General Accounting Office reports, and numerous other important information sources, GPO Access can be reached through many federal depository library gateways nationwide including Purdue University's THORplus World Wide Web site < http://thorplus. lib.purdue.edu/gpo/ $>$.

Other U.S. government military policy and strategy publications available on Internet include the following.

\section{Armed Service Branches}

U.S. Air Force. Air Force Issues Book. Washington, DC: United States Air Force, 1995. < http://www.dtic. dla.mil/airforcelink/pubs/afissues/1995/ $>$.

Electronic edition of the air force's Joint Posture hearing statement presented to congress by Air Force Secretary Sheila Widnall and Chief of Staff General Ronald R. Fogleman.

Broad topical coverage focuses on current air force operations, maintaining combat readiness, shaping the future air force, personnel support, and taxpayer obligations. Issues addressed within these areas include combat training, global mobility, space launch, joint flight training, managing deployment stress, quality initiatives, and industry partnerships.

\section{U.S. Army. America's Army of the 21st Century Force} XXI Meeting the 21st Century Challenge. Fort Huachuca, AZ: Fort Huachuca, 1995. < http://204.7. 227.67/force21/f21/book/book-toc.html $>$.

Included are detailed descriptions of twenty-firstcentury army force structure visions and assessments, including a letter from Army Chief of Staff General Gordon R. Sullivan and Secretary of the Army Togo D. West, Jr. Report sections address the components of the twenty-first-century army, factors influencing that force's development, current army policy development initiatives, and assessment of Force XXI's components.
U.S. Marine Corps. Marine Corps Concepts and Issues for 1995. Washington, DC: U.S. Marine Corps, 1995. < http://www.hqmc.usmc. mil/r-ci/136.htm>.

This annual overview of marine corps strategy, includes comments by Marine Corps Commandant Carl E. Mundy, Jr., chapters focused on the marines as a force for certainty in unpredictable times, marine concepts and issues, strategies, current operations, major acquisition programs, and a fiscal resources overview.

Subjects covered in greater detail within these parameters include the future of naval warfare, marine corps readiness and infrastructure, counterdrug operations, military support to civil authority, aviation combat element programs, and various marine corps budget programs.

Appendixes feature marine organizational data along with pertinent abbreviations and acronyms.

\section{Security Issues}

U.S. Air Force. Welcome to Spacecast 2020. Maxwell Air Force Base, AL: Air University, 1993-1995. < http://www.au.af.mil/Spacecast/ spacecast.html > .

These documents emanate from a 1993 directive from then-Air Force Chief of Staff General Merrill A. McPeak to identify space technologies and systems enabling U.S. maintenance of air and space military superiority. Spacecast 2020 is a series of reports by various air force commands on issues involved in achieving these objectives.

Contents of the introduction include speeches by General McPeak on ensuring technological pre-eminence and information infrastructure construction.

The principal feature of Spacecast 2020 consists of a four-volume technical report. Volume I contains writings examining topics such as space traffic control, rapid space force reconstitution, projecting information power in peace and war, twenty-first-century navigation and data fusion, and achieving military supremacy in space through offensive and defensive measures.

Topics addressed in subsequent volumes include force application, counterforce weather control, and characteristics of future information demand systems for joint warfighting forces.

U.S. Army. Center for Army Lessons Learned. Handbook for the Soldier in Operations Other Than War. Fort Leavenworth, KS: Center for Army Lessons Learned, 1994. < http://call.army.mil:1100/call/ handbooks/94-4.944toc.htm $>$.

This July 1994 publication presents practical guidance for U.S. military personnel engaged in operations other than military combat. 
Principal chapters provide guidance on appropriate tactics, techniques, and procedures for situations other than war and preventive medical procedures. Issues covered within these parameters include checkpoint guidelines, installation security, negotiation, soldier discipline, personal hygiene, communicable diseases, potable water, heat injuries, and field sanitation.

An appendix features checklists for airfield security, roadblock priority intelligence requirements, base defense plans, and patrolling.

\section{U.S. Army. George C. Marshall European Center for} Security Studies. Civil-Military Relations and the Consolidation of Democracy. Washington, DC: George C. Marshall European Center for Security Studies, 1995. < http://www.marshall.adsn.int/net/nedmc. html $>$.

This document represents the proceedings of a 1314 March 1995 conference by the Marshall Center and National Endowment for Democracy on democratic military forces after the Cold War and civil-military relations in developing countries and the post-communist world.

Noted military affairs scholar Samuel P. Huntington (Harvard University) presented the keynote address. Topics discussed include the post-Cold War missions of democratic military forces as well as civil-military relations in developing and formerly communist nations.

\section{Weapons Systems}

U.S. Ballistic Missile Defense Organization. National Missile Defense. Washington, DC: Ballistic Missile Defense Organization, 1995. < http://www.acq.osd. $\mathrm{mil} / \mathrm{bmdo} / \mathrm{bmdolink} / \mathrm{html} / \mathrm{nmd}$.html $>$.

This document provides an overview of U.S. efforts to combat global ballistic missile threats to national security. Areas covered include ground-based interceptors and radar, battle management command, control, and communications, and space-based infrared systems. It also provides estimated deployment timetables for these respective systems.

U.S. Ballistic Missile Defense Organization. Theater Missile Defense. Washington, DC: Ballistic Missile Defense Organization, 1995. < http://www.acq.osd. $\mathrm{mil} / \mathrm{bmdo} / \mathrm{bmdolink} / \mathrm{html} / \mathrm{tmd}$.html $>$.

Presented is an overview of U.S. theater missile defense program components designed to combat shorter-range tactical ballistic missiles. Specific features and weapons systems covered include the Hawk air defense system, Patriot missile, navy area defense, theater high-altitude area defense system, medium extended air defense system, boost-phase interceptor, and system test and evaluation.

U.S. Department of Defense. Joint Advanced Strike Technology Program. 1994 Annual Report and Master Plan. Washington, DC: U.S. Department of Defense, 1994. < http://www.jast.mil/masterplan/mptoc.html > .

This report covers plans for the development, production, and support of future strike weapon systems for the navy, marine corps, air force, and allied nations.

An introductory chapter outlines the purpose, direction, and scope of the Joint Advanced Strike Technology (JAST) program. Later chapters cover JAST management issues, program affordability, integration and analysis, program requirements, technology, program protection and security, and budgetary resources.

Appendixes feature integrated master plan architecture, important technology building block schedules and milestones, investment strategy, and broad agency announcement contract awards.

\section{NOTES}

1. Former Secretary of State James Baker dates the Cold War's conclusion as beginning with the issuance of a joint U.S.-Soviet statement condemning Iraq's 2 August 1990 invasion of Kuwait. See James A. Baker, III, The Politics of Diplomacy: Revolution, War and Peace, 1989-1992 (New York: G.P. Putnam's Sons, 1995), 16.

2. President of the United States, A National Security Strategy of Engagement and Enlargement, (Washington, DC: GPO, 1995), i.

3. Edward N. Luttwak, "Toward Post-Heroic Warfare," Foreign Affairs 74:3 (May-June 1995): 111.

4. Federal defense expenditures from 1962 to the present can be found in U.S. Office of Management and Budget, Budget of the United States Government Fiscal Year 1996: Historical Tables (Washington, DC: GPO, 1995), 58-62. Current historical U.S. military force personnel statistics can be found in U.S. Department of Defense, Selected Manpower Statistics: Fiscal Year 1993 (Washington, DC: GPO, 1994), 172, and U.S. Bureau of the Census, Statistical Abstract of the United States 1995: The National Databook (Washington, DC: GPO, 1995), 364. 
everything into consideration, users should become familiar with the data by using the DCED gopher, and then use the other services for more current data and trade leads. The whole question of how budget cuts are going to affect the collection, time series integrity, and archivability of the data influence file suppliers.
Other challenges, such as how to handle large worksheet programs, are being addressed by Peeper and Business Cycle Indicators (BCI) Data Manager. One certainty is that anyone needing economic data or trade leads should always try the Economic Bulletin Board in whatever form.

\section{(Continued from page 52)}

5. Andrew Kohut and Robert C. Toth, "Arms and the People," Foreign Affairs 73:6 (November/December 1994): 47, 55.

6. A National Security Strategy, i.
7. A National Security Strategy, 33.

8. U.S. Joint Chiefs of Staff, National Military Strategy of the United States of America 1995: A Strategy of Flexible and Selective Engagement, (Washington, DC: GPO, 1995), i-iii, 18.

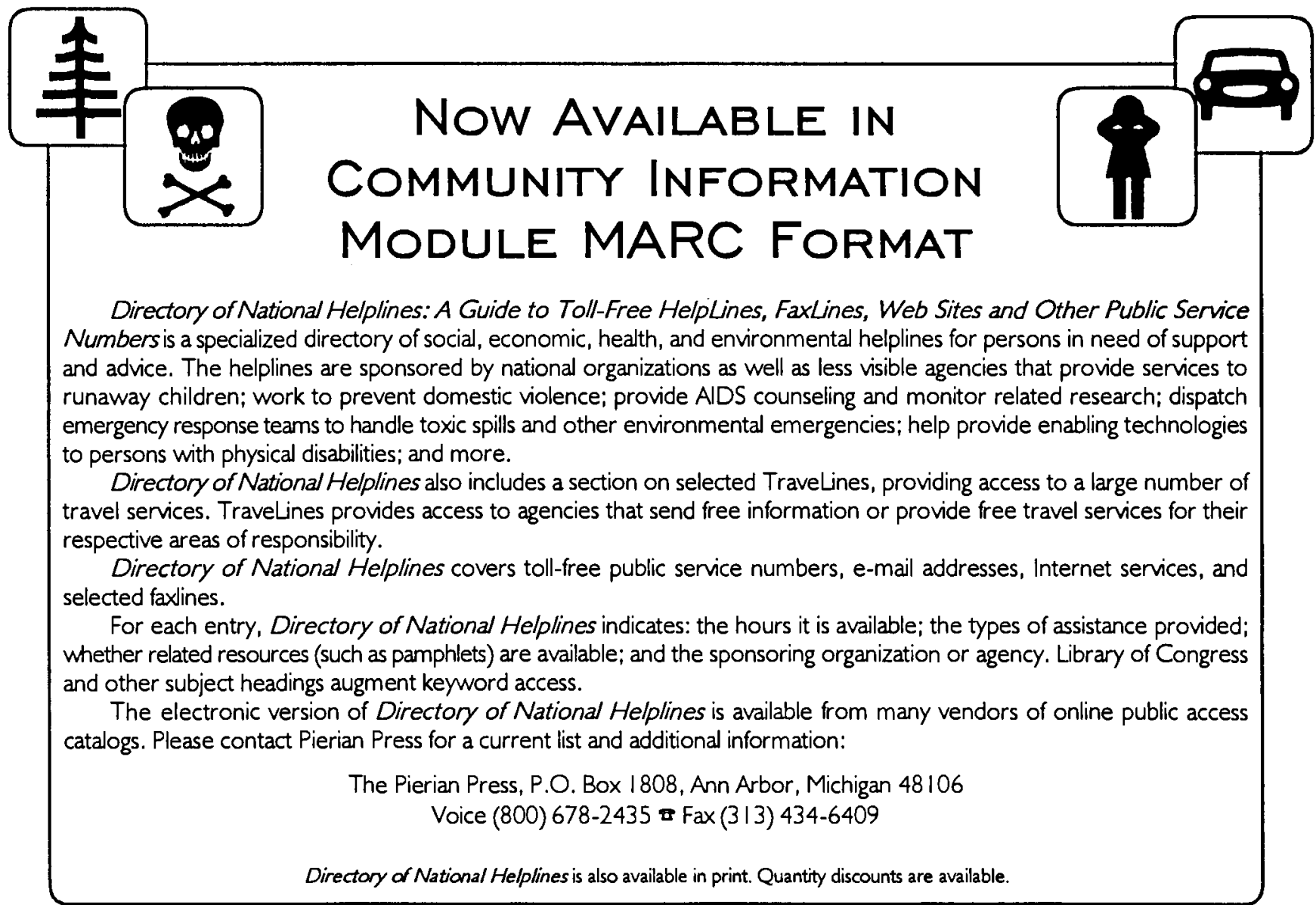

